\title{
Virology, DNA Viruses, Papovavirus
}

National Cancer Institute

\section{Source}

National Cancer Institute. Virology, DNA Viruses, Papovavirus. NCI Thesaurus. Code C19117.

The study of papova viruses and the diseases they cause. 